\title{
Peace and Conflict Studies
}

\section{The Trouble with Truth-telling: Preliminary Reflections on Truth and Justice in Post-war Liberia}

\author{
Gabriel Twose Ph.D. \\ gtwose@apa.org \\ Caitlin O. Mahoney Ph.D. \\ Metropolitan State University, caitlin.mahoney@metrostate.edu
}

Follow this and additional works at: https://nsuworks.nova.edu/pcs

Part of the African Studies Commons, Community Psychology Commons, Criminology and Criminal Justice Commons, Multicultural Psychology Commons, Peace and Conflict Studies Commons, Policy Design, Analysis, and Evaluation Commons, Social Influence and Political Communication Commons, and the Social Psychology Commons

\section{Recommended Citation}

Twose, Gabriel Ph.D. and Mahoney, Caitlin O. Ph.D. (2015) "The Trouble with Truth-telling: Preliminary Reflections on Truth and Justice in Post-war Liberia," Peace and Conflict Studies: Vol. 22 : No. 2 , Article 1. DOI: $10.46743 / 1082-7307 / 2015.1287$

Available at: https://nsuworks.nova.edu/pcs/vol22/iss2/1

This Article is brought to you for free and open access by the Peace \& Conflict Studies at NSUWorks. It has been accepted for inclusion in Peace and Conflict Studies by an authorized editor of NSUWorks. For more information, please contact nsuworks@nova.edu.

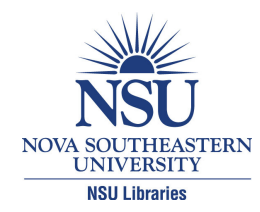




\section{The Trouble with Truth-telling: Preliminary Reflections on Truth and Justice in Post-war Liberia}

\section{Abstract}

This study investigates perceptions of the Liberian Truth and Reconciliation Commission (TRC), particularly focusing on understandings of, and the links between, truth, justice, and reconciliation. Fortyfive semi-structured interviews were conducted at three research sites in Liberia. Findings indicate that although most Liberians agreed with the TRC in principle, most of those who followed its proceedings saw major problems in its implementation, harming perceptions of reconciliation. Participants expressed concerns that the Commission had failed to discover the full truth of wartime abuses, that the truth that was discovered was not told in the right way, and that there had been problems implementing justice. The data indicates that societies recovering from violence and suffering must think carefully about how to revisit their pasts. In order for a truth commission to have a positive impact, it must ensure that truth is told in a reconciliatory fashion, and that its justice-based strategy enjoys popular support.

Keywords: Truth commission, truth, justice, reconciliation, Liberia

\section{Author Bio(s)}

Gabriel Twose is a Senior Legislative and Federal Affairs Officer at the American Psychological Association's Public Interest Government Relations Office, where his portfolio includes human rights and socioeconomic status. He works with Members of Congress and their staff to provide psychology's input into research priorities and federal policies, and coordinates support for legislation and issue positions. $\mathrm{He}$ is responsible for legislative analysis and reports, and relevant APA position papers, policy statements, briefing sheets and newsletter articles.

Prior to joining APA, Twose was the policy director at the Society for the Psychological Study of Social Issues (SPSSI), where he initiated SPSSI's first congressional seminar series, legislative engagement days, and policy workshops. He has previously worked with the Tom Lantos Human Rights Commission in the U.S. House of Representatives and the International Center for Transitional Justice in Monrovia, Liberia.

Twose received his Ph.D. from Clark University, where he wrote his dissertation on the Liberian Truth and Reconciliation Commission.

Caitlin O. Mahoney received her B.A. in psychology from Siena College and her Ph.D. (Social, Evolutionary and Cultural Psychology) from Clark University, with a concentration in societal peace and conflict. She is currently working as Assistant Professor of Psychology at Metropolitan State University in St. Paul, MN, where she teaches classes in Research Methods, Group Dynamics, Positive Psychology \& the Psychology of Peace, Conflict, and Violence. Mahoney has researched and written on emotions, responses to suffering, human security, and peaceful norms. She currently serves on the Executive Board of the Society for the Study of Peace, Conflict, and Violence (APA Div. 48), as Program Evaluator for the Auschwitz Institute for Peace and Reconciliation (AIPR), and as Program Director of Metropolitan State's Master of Arts in Psychology. 


\section{The Trouble with Truth-telling: \\ Preliminary Reflections on Truth and Justice in Post-war Liberia}

\section{Gabriel Twose and Caitlin O. Mahoney}

\section{Introduction}

Forty percent of post-conflict societies revert back to conflict within a decade (Collier, Hoeffler, \& Soderhorn, 2006), while fully ninety percent of the last decade’s civil wars were continuations of recent cycles of violence (World Bank Development Report, 2011). These damning statistics emphasize the fragility of "post-conflict” states and the necessity of addressing legacies of violence. Following a transition from an oppressive rule or civil disorder, societies must straddle the divide between moving on from the violent past and confronting the crimes that have occurred, a field that has come to be known as transitional justice (Teitel, 2003).

Transitional justice, in its modern version, is generally thought of as beginning with the post-World War II Nuremberg trials, inspiring a legalistic model. Subsequent decades have featured a plethora of socio-political transitions with the end of the Cold War particularly influential in inspiring a wave of liberalization (Freeman, 2006). Many of these transitions were characterized by former perpetrators retaining some degree of power and influence, leading to political dilemmas in terms of facing the past. The ideal rule of law somewhat succumbed to pragmatic principles based on the unique contextual factors of each situation, including the scale of wrongdoing, the influence of the wrongdoers, and the competence of the judiciary (Teitel, 2003). The goals of transitional justice have since been broadened to encompass more than purely legal norms. One such departure is the growing acceptance of restorative approaches, which incorporate concepts such as forgiveness and reconciliation. The transitional justice toolbox has widened to include moral, religious, and psychological dimensions, which address a wider range of social and political goals (Bell, 2009).

\section{Truth Commissions}

As part of this toolbox, one of the most common transitional justice mechanisms in recent decades has been the implementation of truth commissions. Despite their 
frequency, there remains some disagreement over the specific definition of a truth commission. The most commonly cited work is Priscilla Hayner's Unspeakable Truths (2011), which states that a truth commission must: focus on the past; investigate a pattern of events; engage directly with the affected population; be temporary; and be officially authorized by the state. There has been a great deal of theoretical research into truth commissions, but with several notable exceptions (e.g., Gibson, 2006; Millar, 2011; Mullet, Neto, \& Coneicao Pinto, 2008), little systematic empirical investigation of the views of a truth commission's audience, the citizens of the post-conflict society. Since they are the ones to be reconciled, it is vital to investigate their opinions of the purpose or outcome of such a body. Appraisals of mechanisms such as truth commissions are vital in affecting consequent emotions, behaviors, and human rights support (Leidner \& Li, 2015). Hence, this paper will seek to investigate public reactions to one such truth commission, focusing on perceptions of truth and justice, and how these concepts are linked to reconciliation.

Truth commission mechanisms. Truth commissions often make recommendations regarding political, social, or security sector reform, but depending on governmental will, these recommendations may or may not be implemented. Beyond recommendations, the methods through which truth commissions actually aid postconflict societies remain somewhat controversial (Olsen, Payne, \& Reiter, 2010; Weibelhaus-Brahm, 2010). Minow (1998, p. 9) suggests that the pursuit of truth and some form of justice underlies the potential effectiveness of truth commissions in societies which strive toward reconciliation as a public goal. Each of these complicated, contextual terms deserve unpacking.

A truth commission may promote truth. The most basic method truth commissions use to achieve their objectives is the discovery of previously unknown facts. Most of the earlier Latin American truth commissions (e.g., Argentina's or Chile’s) took place in societies that had been characterized by governmental oppression, and there was a great deal of hidden information to be discovered. “Truth seeking” was a priority in situations such as these (Millar, 2010). In other situations though, particularly in the aftermath of war, the onus may be slightly different. Since the South African commission, many truth commissions aim to bring into the open and publicize what is 
known but not spoken. As the truth commission model developed, with South Africa's TRC as the turning point, commissions have utilized increasingly advanced methods of “truth-telling” (Millar, 2010), and widely publicized public hearings have become the norm (Freeman, 2006).

Truth-seeking and -telling are hoped to help survivors by promoting psychological healing (e.g., Lederach, 1997; Kriesberg, 2004) and justice (Teitel, 2003). Commissioners and statement-takers may listen to victim stories, hold public hearings, and publish a report recounting survivor experiences (Hayner, 2011). Accordingly, survivors are given a voice, and their experiences are brought to public attention, with the aim of mainstreaming what has been marginalized, providing official acknowledgement of abuse (Hamber, 2008).

Truth-seeking and -telling may also aid bystanders, or society at large. George Santayana (1905) famously argued that those who cannot remember the past are condemned to repeat it. Accordingly, a society must discover and remember what happened so that they can prevent it from happening again. Through discovering what had been secret, or through hearing tales of suffering and apology, it is thought that previously antagonistic individuals or groups may be helped to leave their grievances behind, leading to a kind of "social catharsis” (Pupavac, 2004).

However, several researchers have questioned the universal efficacy of the truthinvestigation and -publicity model. Rosalind Shaw (2005) argues that in Sierra Leone, "social forgetting is a cornerstone of established processes of reintegration and healing" (p. 1). Millar (2011), builds on Shaw's research, concluding that local cultural dynamics worked against acceptance of the truth-seeking model in Sierra Leone. In actuality, the unearthing of the country's history of violence aided neither healing nor justice, and was seen as undermining local concepts of individual agency and secrecy.

A truth commission may promote justice. Many scholars argue that trials and accountability are necessary to create an enduring peace (Goldstone, 1996). Truth commissions often contribute to this kind of retributive justice through recommendations that can lead to criminal trials or other sanctions, but depending on political will, these recommendations may never be enacted (Hayner, 2011). Offering survivors a full accounting of previously denied 'truths' (Landsman, 1996) or publicly shaming 
perpetrators (Bloomfield, Barnes, \& Huyse, 2003) may also be conceived as contributing to justice. Alternatively, a truth commission may emphasize a more holistic kind of restorative justice, stressing community rather than punishment. This entails reempowering and restoring the dignity of survivors, managing demands for retribution, and stressing the interconnected humanity of society members (Villa-Vicencio, 2004). In this sense, justice necessitates addressing the damages suffered by individuals and communities in order to restore collective relations (Leebaw, 2003).

Retributive and restorative justice are often juxtaposed, argued to be contradictory and irreconcilable. But the distinction tends to be oversimplified, hiding the complex dynamics surrounding justice and reconciliation (Lambourne, 2009). Many approaches combine both restorative and retributive elements. Rwanda's gacaca courts, for example, were primarily restorative in nature, but meted out punishments. They required offenders to appreciate the gravity of their crimes, and the outcome was thought of as punishment, albeit a penalty not so severe as to interfere with community reconciliation (Molenaar, 2005). Hence, boundaries between these two approaches have become blurred and context specific, as various elements of both approaches may be combined in keeping with the values of the community (Quinn, 2005).

A truth commission may aim to advance reconciliation. Truth and justice may have several goals. Especially since the paradigmatic South African Truth and Reconciliation Commission, primary among these goals is often the promotion of reconciliation. There are many ways to define whether a society is "reconciled.” Space precludes a thorough literature review, but Bar Siman-Tov (2004) writes that reconciliation is based on transforming relations from hostility and resentment to friendship and harmony, and Bar-Tal (2009) concurs, describing reconciliation as the development of "mutual recognition and acceptance, invested interests and goals in developing peaceful relations, mutual trust, and positive attitudes, as well as sensitivity and consideration of (the) other party’s needs and interests” (p. 368). He refers to a change in the societal "repertoire" which is elsewhere elaborated as encompassing an alteration in beliefs, attitudes, goals, and emotions resulting in new norms, opinions, values, and memories (e.g., Bar-Siman-Tov, 2004; Kelman, 1999; Lederach, 1997). 
Some theorists, though, take a more pragmatic approach, denying the necessity of acceptance or forgiveness in the context of mass atrocity that is so entrenched in history. Hayes (1998) proposes, "Reconciliation is not about the (individualism of) forgiveness of the dreadful and vile acts committed...but how all of us are going to act to build a new society” (p. 33), and Borneman (2002) concurs, defining reconciliation as "an agreement among antagonistic subjects to depart from violence in a shared present” (p. 300). A minimal perspective on reconciliation asserts that in the aftermath of mass atrocity, tolerance and coexistence are all that can be hoped (Gardner Feldman, 1999).

Truth commissions utilize publicity. In order to affect broad societal reconciliation (however defined), both truth and justice must be publicly delivered so that the audience is aware of what has been achieved. As David Crane, the original lead prosecutor for the Special Court for Sierra Leone argued, it is not necessarily that justice is done, but that "justice is perceived to be done" (cited in Millar, 2011, p. 517). Hence the perception of truth and justice is perhaps just as important as the actual truth and justice delivered in affecting cognitive and emotional reactions to the commission. Thus, the public uncovering of truth and the promotion of justice are potentially underlying mechanisms through which a truth commission may promote reconciliation.

There is, however, little empirical support for the salutary effects of truth and justice perceptions, and the evidence that does exist does not permit firm conclusions as to the benefits of truth-telling, truth-seeking, or justice delivery (Mendeloff, 2009). Additionally, the preponderance of relevant empirical research has been conducted (1) on the best-known and -regarded commissions, creating a biased sample, and (2) on those who personally testify, who make up a relatively small proportion of the population. In terms of sheer numbers, a broader society must be affected by a truth commission in order to bring about widespread reconciliation. Recent large-scale quantitative comparative investigations (e.g., Kim \& Sikkink, 2010; Olsen, Payne, \& Reiter, 2010), while hugely valuable in describing societal level effects of truth commissions, tend to be less effective in terms of uncovering the nuanced pathways of their impacts. To grow our understanding of whether and how truth commissions impact the beliefs and attitudes of local citizens, detailed perceptions of a recent truth commission must be examined. 
Liberia's Truth and Reconciliation Commission, established in 2005, offers one such opportunity to examine a contemporary case in such detail.

\section{Liberia}

Liberia was established in 1822, by the American Colonization Society, as a province for freed American slaves. Arguably, the historically abusive relationship that followed between freed slaves and native populations set the bedrock for the horrific civil war that would ensue (Levitt, 2005; The 150+ year evolution of conflict in Liberia goes beyond the remit of this paper, but the interested reader is encouraged to consult, for example, The Evolution of Deadly Conflict in Liberia (Levitt, 2005) or The Mask of Anarchy (Ellis, 1999). Beginning in 1989, more than a decade of violent conflict had grievous consequences for the nation (Levitt, 2005, Williams, 2002). Almost all citizens were affected by the war, either through direct exposure to violence or through requisite flight from the country, many finding themselves in refugee camps. Estimates of fatalities vary from 60,000 to 200,000 (e.g., Ellis, 1999, Moran, 2006). The government and various rebel forces finally signed a lasting Comprehensive Peace Agreement in Accra, Ghana in 2003 (Hayner, 2007). The presence of the warring parties at the negotiations meant that a war crimes tribunal was unlikely, but a blanket amnesty would have been tantamount to admitting wrongdoing in front of international and civil society observers (Steinberg, 2009). The warring factions eventually agreed upon the compromise of a truth commission (Sleh, Toe, \& Weah, 2008).

\section{Truth and Reconciliation Commission}

The Liberian Truth and Reconciliation Commission (TRC) was ultimately established in June 2005, the Commissioners were inaugurated in February 2006, and hearings were held in 2008. The Truth and Reconciliation Act instructed the TRC to investigate Liberia's history of violence in order "to promote national peace, security, unity, and reconciliation” (National Transitional Legislative Assembly, 2005). However, the Commission was beset by problems from its inception. Many of the most prominent perpetrators did not recognize the authority of the Commission, and most of those who testified treated the Commissioners with disrespect, for example referring to them as 'pekin’ ('little boy' in Liberian English; Steinberg, 2009). The Commission's report itself is problematic, as there are no clear links between individuals recommended for 
sanctions and the crimes of which they are accused (James-Allen, Weah, \& Goodfriend, 2010) and there are no obvious criteria for determining who is and is not to be held accountable (Steinberg, 2009). The Commissioners did not agree on how to advance reconciliation, highlighted by the fact that Muslim leader Sheik Kafumba Konneh and lawyer Pearl Brown Bull refused to endorse the Commission's final report (Harris \& Lapin, 2010) due to its insistence on what they perceived as unhelpful prosecutions and lustration.

Despite these weaknesses, the Commissioners investigated human rights violations and violations of international humanitarian law, eventually collecting an impressive total of 20,560 statements from Liberia’s 15 counties (Truth and Reconciliation Commission of Liberia, 2009). The TRC held more than 800 hearings, the vast majority of which were public, in order to engage the Liberian populace (Verdier, 2008). Dovetailing with the model of truth commissions’ promotion of reconciliation described above, stressing truth, justice, and publicity, Commission Chairman Jerome Verdier described the primary objectives of the public hearings as, first, discovering previously unknown truths about wartime abuse, and second, delivering some form of justice to all perpetrators, at a minimum through public moral censure (personal communication, 8/8/2010). Because these constructs form the frame of inquiry and analysis that follows, and especially because their construction is highly localized, we must first disentangle the contextual basis for truth, justice, and publicity in Liberia's reconciliatory process.

TRC's truth. Although modeled on the South African TRC, it is important to keep in mind the very different circumstances in Liberia. As stated above, earlier Latin American truth commissions aimed to discover hidden information, to seek truth (Millar, 2010). In the context of a civil war though, less is systematically concealed. Hence, as much as discovering truth, the Liberian TRC aimed to "break the silence about widely known but unspoken truths” (Hayner, 2011, p. 20), to tell truth. However, it is not clear whether these two types of truth - seeking and telling - are envisioned as distinct in Liberia, and if so, which is more essential to the process of reconciliation.

TRC's justice. The Commission had a contentious connection to justice, making controversial recommendations regarding prosecution, vetting, and amnesty. However, 


\section{Peace and Conflict Studies}

in the years since the TRC tabled its final report, no one has been indicted for wartime crimes, and, due to the fact that many of the perpetrators remain in positions of power, it is likely that they will never be charged (Harris \& Lapin, 2010). Several warlords, previously opponents of one another, together warned that if the recommendations were enforced, Liberia would slide back into instability (Weah, 2011). In fact, mandatory implementation of the TRC's recommendations has been ruled unconstitutional (Supreme Court of Liberia, 2011), and it has been argued that the lack of retributive justice has created a great deal of antipathy among Liberians (Steinberg, 2009). In this case, if justice is not perceived as just, the public nature of the TRC may heighten disillusionment, potentially harming national reconciliation.

TRC's publicity. The TRC conducted extensive training with the International Media Center and the Press Union of Liberia and established a department of media affairs, hoping to ensure that the media would contribute to engaging the Liberian populace in the reconciliatory movement (Truth and Reconciliation Commission of Liberia, 2009). An initial analysis of the media at the time of the TRC indicated that about $5-10 \%$ of total newspaper and radio content space was devoted to Commission coverage (Randall \& Pulano, 2008). A more recent survey showed that $73 \%$ of Liberians have heard of the TRC and 76\% believe the truth to be important. However, just 44\% believe the truth about the fighting is known, calling into question the degree to which the silence was ever widely broken. Most reported little (46\%) or no (45\%) knowledge about the TRC (Vinck, Pham, \& Kreutzer, 2011), and in any case, particularly given the controversy surrounding the Commission's proceedings and recommendations, the effects of familiarity remain unclear.

\section{Current Study}

Many scholars have heavily criticized the Liberian Truth and Reconciliation Commission. Cruz-Gitau (2008) calls some aspects of the Commission "demonstrably weak” and references “damaging publicity” for the Commission. Gberie (2008) accuses the commissioners of "moral confusion." Steinberg (2009) calls the hearings a "fiasco" and describes the "wounding criticism" aimed at the Commission by observers.] Citing cultural inappropriateness, an unclear mandate, lack of credibility, flawed methodology and report, and inconsistent recommendations, Harris and Lapin (2010) argue that the 


\section{Peace and Conflict Studies}

TRC was potentially more divisive than reconciliatory. Other researchers, such as Weah (2011), draw more positive conclusions, claiming that despite the lack of follow-through, the Liberian public was excited about the accountability delivered by the TRC's report.

What is generally absent in these accounts, however, are the direct voices of the truth commission's audience, the Liberian public. Since they are the ones to reconcile with one another, this seems an important omission. Hence, this research investigates public perceptions of the delivery of truth and justice. How much is its audience aware of the TRC's mandate? Are they conscious of its procedures or of its success (or lack thereof)? What kind of truth needs airing and what sort of justice would people like to see implemented? What does reconciliation even mean in Liberia? Do perceptions of truth uncovered and justice delivered have any bearing on reconciliation?

\section{Methods}

\section{Research sites}

Due to its public awareness campaign and the fact that hearings took place in all County capitals, most Liberians are aware of the TRC (Vinck, Pham, \& Kreutzer, 2011). However, the national capital Monrovia hosted the vast majority of TRC proceedings, and is home to one third of the Liberian population and almost all of the national media. Given these facts, there are likely to be vast differences in exposure to the TRC between people inside and outside of the capital, which will, in all likelihood, lead to differences in opinion of its influence or success. Additionally, we predicted that different levels of exposure to the TRC would lead to differences in TRC knowledge and opinion between County capitals and cities in which the TRC did not hold hearings.

Accordingly, to assess the effect of the TRC's publicity, three research sites were selected, all of which were the locations of heavy wartime fighting: Monrovia, the capital of Liberia (population: 1,010,970), Gbarnga, the capital of Bong County (population: 34,000); and Ganta, a major city in Nimba County (population: 41,000; data from Liberia National Housing and Population Census, 2008). Those in Monrovia were exposed to the majority of TRC hearings, and have access to a wide variety of media coverage. Those in Gbarnga were exposed to some TRC hearings, and have access to less media coverage. Those in Ganta were not exposed to TRC hearings and have access to less media coverage. 


\section{Participants and Recruitment}

In total, 45 interviews were conducted $($ men $=25$, women $=20)$. Participants varied in age from 25 - 56 (although some were not sure of their exact age). They were of varied social status and backgrounds, including students, teachers, market-women, a policeman, a mechanic, a politician, a goldsmith, a security guard, an engineer, etc. As the more educated respondents were more informed about the TRC, their quotes are disproportionately represented in the results section below. However, comparisons between research sites encompass all respondents.

Potential participants were approached on the streets, in the marketplace, at institutes of learning, or at their places of business. We informed them that we were talking to different people about their opinions of the Truth and Reconciliation Commission, and reassured them that we were researchers, not connected to any political party. We often explained that although they personally would not benefit, the research had the potential to help other countries learn from Liberia’s experiences. We decided that monetary compensation would lead many participants to answer questions in the fashion they thought most pleasing rather than providing honest opinions. Hence, participants were provided with refreshments (water or soft drink) for their time, but any financial reimbursement was avoided. Most people were willing to participate, although some (approximately 10-15) chose not to, citing reasons such as lack of knowledge, interest, or time, or desire for privacy or compensation.

\section{Interviews}

Semi-structured interviews were conducted at each research site, over the course of approximately four months. Interviews took place wherever the participant felt most comfortable, sometimes in private (e.g., the home) and sometimes in public (e.g., a café). They were conducted in Standard English - which is spoken by the majority of people in urban Liberia - audio recorded, and later transcribed. Interviews were conducted with the help of a Liberian research assistant, a graduate student at the University of Liberia's Kofi Annan Institute for Conflict Transformation. They varied in length, depending on the knowledge or interest-level of each participant, but the average length was about 25 minutes, ranging from just 10 minutes in several cases, to some that reached about an hour. Many participants were hesitant to talk about unfamiliar concepts, leading to 
shorter than anticipated conversations. The research assistant took the lead in interviews; the primary researcher interjected only when necessary. Given that many participants had never been interviewed before, we aimed to increase their comfort level by having a Liberian conduct the interviews. But by having a non-Liberian present, we aimed to minimize the assumption of shared experiences, encouraging respondents to more fully explain their responses (Miller \& Glassner, 2004).

All interviews began with demographic information, so as to make participants feel more comfortable with simple questions requiring short answers, before broaching more challenging topics. We feared that asking people their tribe could be a sensitive issue, so replaced it with the proxy question of dialect spoken. The specific wording of questions varied, but we endeavored to avoid leading enquiries. We attempted to let the interviews flow as naturally as possible, with questions emerging from previous responses, but tried to ensure that several broad topics were covered, including: Demographic information; Brief summary of war experiences (skipped at participants' request); Exposure to TRC testimony or media coverage; Opinion of revisiting Liberia's past through a truth commission; Opinion of the purpose of TRC; Perception of truth and justice; Opinion of those who specifically harmed the participant or his/her family; Opinion of general reconciliation in Liberia; and Perception of Liberia’s security including the possible return of war.

\section{Data Analysis}

Anchored in the extant theory outlined above, which highlights the importance of a truth commission's publicity of truth and justice, we carried out a deductive qualitative analysis (Gilgun, 2005) over several months. This method of analysis begins with a conceptual model with the intention of testing and refining it, resulting in a more accurate set of hypotheses. The model in this case was composed of a loose set of ideas, based on previous research and theories. We were interested in participants' opinion of the truth commission's aims and activities, in their definitions of truth, justice, and reconciliation, and in their perceptions of reconciliation in Liberia. We were not at all sure what these opinions would look like, or how the variables would fit together. For example, more acceptance of the South African Truth and Reconciliation Commission's truth was linked to reconciliation (Gibson, 2006), but in the very different setting of Liberia, that 


\section{Peace and Conflict Studies}

relationship may not hold true. Hence, we focused on participants' meaning constructions of truth, justice, reconciliation, and the TRC, paying particular attention to the effects of geographical location as a proxy for degree of publicity. Our classification of responses gradually became more selective, reflecting the patterns most substantiated in the data (Charmaz, 2006). The results section below utilizes representative quotes to highlight these patterns, explaining how respondents understood the concepts of truth, justice, and reconciliation, and their opinions of the TRC’s purposes, mechanisms, and outcomes.

\section{Results}

\section{Looking at the Past}

Importantly, most respondents believed that revisiting Liberia's past was at least partially a good idea, an essential first step toward the goal of promoting reconciliation through truth-telling. Just as importantly though, there were substantial differences of opinion as to why people thought the past was being revisited. The vast majority cited “reconciliation" or "forgiving” as a primary goal of the TRC, fitting with previous theoretical (Moosa, 2000) and empirical (Twose, 2010) research that has argued for the symbolic value of truth commissions. For example this woman in Ganta opined that:

They said we should come together; we should put every grudge down to come together. At least, so we can be one. And I like it like that. Because we the Liberians, we are one. So we should come together and reconcile and forgive one another. So forgiving is still going. I want to forgive. Every human got the same heart.

Similarly, a student in Monrovia argued that:

Well I feel that the TRC was trying to, you know, heal the wounds. Call people up to say the things they did, maybe were under the influence of alcohol or under the influence of drugs, and now they have changed, so they come to say sorry for what they did.

In addition to forgiveness, the TRC aimed to address impunity, but only a third of respondents mentioned punishment or justice as a purpose of the Commission. A Gbarnga businessman was among those who did, describing the TRC as: 


\section{Peace and Conflict Studies}

A good thing for this country, to address impunity, because some of us felt that, coming out with these things and identifying our problems, corrective measures would immediately be put in place so there would be no recurrence of this (violence) in times to come.

Those who did not buy into the idea of looking at the past were skeptical for different reasons. Some, such as this market-woman in Ganta, felt that the TRC reopened old wounds, making people angrier:

The TRC was not too fine. Because, for example, somebody kill your mother, then the person come in your presence, in front of you, and say, "I'm the one kill your mother." You know, you will get too angry with that person and you will even like to react... your temper goes, and you want to pay your debt. Others, such as a businessman in Gbarnga, were furious that the Commission was too forgiving of perpetrator's crimes, falling far short of the desired war crimes tribunal:

If I had my own will, we'd set up a war tribunal, to set precedent for the generations to come...But TRC, they say, let me make peace. You kill my ma, then you coming back to me and say just, sorry. I mean, it's just digging old wounds. TRC is not good for Liberian people. Nothing, TRC didn't do for me, as a Liberian...Successful? TRC is trash.

However, this level of anger was unusual; most participants were supportive of the idea of a truth commission. As will be seen below, the respondents' primary objections had to do with its implementation.

Opinions on the utility of looking at the past varied by location, with respondents in Monrovia more likely to be in favor of investigating the past than those in Ganta or Gbarnga. It is interesting to note that participants in Monrovia, where the TRC held the majority of its hearings and most successfully publicized itself, were more convinced of the benefits of investigating the past. This suggests that the TRC's public awareness campaign was successful in persuading people in Liberia’s capital but less so in the further-flung regions of the country.

\section{Truth}

Very few respondents perceived the TRC as completely successful in uncovering the truth about the war, calling into question its truth-seeking efficacy. A variety of 


\section{Peace and Conflict Studies}

reasons were given for these limitations. An agriculture student complained that, "The one aspect that really hurt me was, what they did was, their report left people out who committed atrocities.” A school principal in Gbarnga mirrored the perception that the TRC was a Monrovia-based institution, arguing that the hearings were not widespread enough: "Come to every county, then when you come to Nimba, from the counties, you go to districts. It would be national-wide. It shouldn’t be Monrovia.” Of course, the TRC did actually visit all Counties - perceptions such as these reflect limitations in the Commission's public awareness campaign. Some simply argued that had the Commission discovered the horrors that had occurred, there was no way the perpetrators would still be free:

If TRC was to find out the truth, the people who were involved in the war, greatly, they would be in jail by now. But they're moving freely. So the TRC never found out the truth.

For these people a lack of justice evidenced the lack of truth.

Concurrently, linked to Hayner’s (2011) “widely known but unspoken truths,” people sought truth-telling. In addition to public acknowledgement, respondents wanted perpetrators to admit and express remorse for their crimes. Many participants accused warlords of lying, which implies that the truth about their atrocities was already known. What participants' desired, even more so than discovering new truths, was an admission of guilt, of what was known to be fact. This admission goes hand-in-hand with telling the truth in the right way, ideally incorporating remorse and apologies, an arena in which the TRC was clearly lacking.

For example, a woman in Monrovia called for perpetrators to accept responsibility for their actions: "If the do-er do not accept (responsibility), there might be another chaos...But not boastfully, not arrogantly. You have to accept with a compassion.” But most respondents did not feel that this acceptance took place. Participants alleged that those who testified were guilty of "lying," "boasting," “cheeking” (disrespecting the Commissioners), and "bluffing." So even if the correct people testified, they did not do so correctly, as explained by this student from Monrovia:

TRC brought people that testified who were truly involved in what happened, but they did not say the truth, you understand? They just went and glorified 


\section{Peace and Conflict Studies}

themselves, and some say they had no reason of apologizing to the Liberian people because they didn't do wrong. But realistically these people were $100 \%$ involved in almost everything that happened here negatively.

A policeman in Ganta expanded on this issue, explicitly linking the limitation to reconciliation:

No, truth was not said. Truth was not said really. Other people went in to testify because they want to bluff. Some men's hearts were true, but the majority of them were not saying the real truth. They were just bluffing in what they were saying. We all can reconcile? They were bluffing.

Telling the truth, if carried out in the wrong way, did not advance reconciliation. Without even this minimal sense of personal accountability, the subsequent lack of retributive justice became even more difficult to accept.

Respondents in Ganta, where the TRC did not hold hearings, were the most likely to view the TRC as successful in seeking and telling the truth (although even here, only a third held positive perceptions). Those in Monrovia were by far the most cynical. Not a single Monrovian participant claimed that the TRC was completely successful in uncovering the truth, likely reflecting the increased exposure to the Commission's failures. It appears that the more people were exposed to the proceedings of the Truth and Reconciliation Commission, the less they feel it was able to succeed in its mandate of discovering the truth.

\section{Justice}

As documented elsewhere, Western notions of retributive justice may sometimes be culturally inappropriate in Liberia, incommensurate with more restorative local concepts (Harris \& Lapin, 2010; Vinck, Pham, \& Kreutzer, 2011). According to about half of the participants in this study though, when crimes are as serious as those perpetrated in the war, the discourse of trials and retributory justice dominates. For example, a student in Monrovia opined that justice, in the context of wartime atrocities, means, "You want the law to take its course.” A mechanic in Gbarnga concurred: “Justice? It's to carry to court. You explain what you saw and what happened to you."

The other half of respondents demurred, asking for a different kind of justice. Many of these simply stressed equality or fairness, for example: "What's for you should 


\section{Peace and Conflict Studies}

be given to you, and what's for me should be given to me... What you deserve should be given to you.” One respondent in Gbarnga equated retaliatory justice to fighting, hinting at its divisive nature: "If somebody does wrong to me... and you really tell me that this guy is wrong to me, it's justice, and you're trying to pick the fight.” Several others described justice as simply “peace,” stressing the war-fatigue present in so many Liberians. Just two participants referenced victim reparations as a component of the necessary justice, hinting that the treatment of perpetrators is front and center in the national consciousness.

About half of those surveyed felt that Liberia needs retributive justice immediately in order to move beyond its history of violence, supporting researchers who argue for the necessity of such an approach (e.g., Goldstone, 1996). Although several participants who desired justice said that apologies (which never materialized) would have been enough, the majority stressed the necessity of punishment as deterrence against future crimes. A sociology student in Monrovia exemplifies this sentiment:

Someone will come and say, "Yes, I kill her mother, and I kill her children and the whole family, I burn the whole nation” and nothing is done. It's like you're encouraging other people to do the same thing.

It is important to note the rationale for many Liberians' support for retributive justice. Based on the nomenclature alone, one might suspect that they seek retribution. However, in actuality, this type of justice was predominantly desired in order to deter future violence. The distinction commonly drawn between retributive and restorative justice is not especially relevant; healing and reconciliation are not separate from prosecution and punishment. In order to restore their country to a state of peace and stability, many people felt that "justice must be done" in order to prevent impunity. Most participants simply wanted to live in peace, but viewed prosecutions as a necessary way to get there. "Retributive" actions must be taken in order to further "restorative” ends, continuing the mixed approach taken by Rwanda’s gacaca courts (Molenaar, 2005), or by the South African Truth and Reconciliation Commission, which also blurred retributive and restorative lines (Villa-Vicencio, 2004).

Stressing the opposing view, an eloquent university administrator denied the necessity, or even helpfulness, of immediate justice, instead pleading for practicality: 


\section{Peace and Conflict Studies}

What are you going to do? You bringing in some hatred or hard feeling that will lead the people gather their force and go back in the bush again. We want to see

Liberia move forward. Let bygones be bygones. Let them forget about it...you have to be practical, practicality go along with justice.

Although truth commissions deal with the past, there is a great deal of concern with the future, and how to best prevent a recurrence of violence. With no deterrence, which many people felt should take the form of accountability through trials, some felt that the conflict could reignite. However, others feared that with forced prosecutions, Liberia could quickly slide back to war.

Many participants were angry about the TRC’s justice-related recommendations. This anger stemmed from two primary sources. First, a number of respondents felt that the Commission's recommendations dangerously exceeded its mandate. They claimed that the recommended trials would destabilize an already fragile country. For example, a first-year university student in Monrovia felt that Liberians would reconcile themselves given sufficient time and dialogue, and that the TRC's recommendations would only hurt the process. He argued:

The recommendations state that those that were involved in the war, that committed certain categories of crime, should be punished. They should be given sentences, traveling bans, and what have you...That is NOT the function of the TRC. The function of the TRC is to reconcile the people.

A second group felt that Liberia needs accountability, primarily through retributive justice, to deter future violators. This group was angry that the TRC's recommendations have been ignored (or they simply did not know about the recommendations, viewing the Commission as allowing perpetrators to remain unpunished). A business student asserted that:

Essentially the act of the TRC states the report shall not be subject to any legislative approval. It means that the report is meant to be implemented immediately by the executive...to bring forth justice. So the executive is part of the whole thing, and refuses to implement the law.

Very few participants claimed that the TRC delivered justice. Those that disagreed were either using a minimal definition of the term (e.g., justice = peace; we are 


\section{Peace and Conflict Studies}

not at war now, therefore we must have justice), or had a mistaken view of what the Commission accomplished, believing that perpetrators had been tried for their crimes. Interestingly, those that felt the TRC delivered justice were generally in Ganta (although less than a third of Ganta-based participants held this view), which also hosted the majority of the participants who believed that the TRC had uncovered the truth about the war. This similarity supports the tentative conclusion that those individuals who were less informed about the Commission believe it to be more successful.

\section{Reconciliation}

Participants generally defined reconciliation as moving on from a divisive past and living peacefully with former opponents. A Gbarnga man called reconciliation, "coming together to find a way forward so that history cannot be repeated," and a small businesswoman in Ganta concurred, defining it as: "to leave everything, for us to come together and be one.” Many people referenced the need to "forgive and forget," or to "let bygones be bygones," phrases which appear to have gained popular currency in the aftermath of the war. Referencing the necessity of coming to terms with the past, one female student explained reconciliation as "to come to one understanding," while many participants similarly stressed the necessity of dialogue.

However, many participants utilized a minimalist, practical rationale for reconciliation, as exemplified by this Monrovian:

Reconciliation, to me, is allowing whatever happened, whatever bad thing that happened, just to pass for the sake of peace. Allow whatever happened just to pass for the sake of peace. So for peace, coexistence, and harmony - that right environment to work together.

This sentiment links with many theorists who have denied that forgiveness must be a precursor for conflict resolution (Borneman 2002; Gardner Feldman, 1999; Hayes, 1998). A student in Monrovia, meeting a former soldier who shot him, demonstrated that forgiveness may sometimes be infeasible:

He said, “I beg you, forget about that thing.” I said, "I’m sorry, I don’t have the time to help you with your oil.” So I left him. I do not have anything against him; I would not go for him. Whatever has happened has already happened from my perspective. 


\section{Peace and Conflict Studies}

The student was willing to refrain from revenge, but would not deign to help the man who had harmed him. He was able to live peacefully, sharing a country with those who had abused him, but forgiveness or friendship were, at this point, unrealistic goals.

Despite acknowledgement from some that coexistence and renewed relationships were difficult if not impossible, most respondents claimed to be reconciled (however minimally), to have moved on from their pasts and forgiven those who hurt them. When asked about personal reconciliation, the majority of interviewees responded affirmatively: “I’ve already forgiven him. He can come here and we'll sit together, drink. So I don't see that would be a problem for me," or, "Some people do bad to us and we forgive. During the war, there are some people they beat us, today we see them on the street, take \$5 (Liberian) from our pocket and give it to them. You've just got to forgive.”

But when the issue of reconciliation was broadened to encompass the rest of Liberia, respondents typically answered differently, with only about a third of the participants responding positively. Typical replies included, “They didn’t really, in my opinion, succeed in reconciling the people, because several core issues were not addressed,” or, "Well, every day, for now, when you listen to the radio...some people not feeling happy.” The difference is captured by this Monrovian student:

I forgive all those who hurt me, those that destroy my life...even those that killed my friends, my family. I forgive them; I'm willing to forgive. But the fact is that there are many Liberians out there that might not think the way I'm thinking. They might not be willing to forgive.

When all responses were considered together, the dichotomy between claims of individual reconciliation and perceptions of societal reconciliation was striking. The sharp difference forces one to wonder whether, when stating their personal views, people simply give the socially desirable, “correct” answer, while reflecting on the country at large may have enabled them to respond more honestly. As such, the number of people who claim to be reconciled and to have moved on from the past should be interpreted with some skepticism.

Participants’ avowed beliefs about the possibility of war returning were painted with a similarly 'rosy glow'. Although the vast majority said that war was unlikely or impossible, there was an aspirational quality to many responses, characterized by a 


\section{Peace and Conflict Studies}

teacher in Gbarnga: “I don’t want war again in Liberia, to be frank. War will never come again. Nothing. We are tired. War can destroy, war can carry you back.” Similarly, a market-woman in Ganta noted, “We don’t want it [war] to come. It will not come. It will never come.” People seem to be trying to convince themselves that war will not return.

There was a definite difference between the claims of both personal and societal reconciliation according to geographic location. Participants in Ganta were more likely than those in Monrovia or Gbarnga to claim that they themselves, and the country as a whole, were reconciled. Although the numbers are limited, the convergence is striking: In the areas where the TRC held hearings, participants were less likely to believe it to be successful and were less likely to claim personal or national reconciliation.

The statements of several participants directly support this conclusion. For example, a goldsmith who closely followed the activities of the TRC through newspaper and radio asserted:

The things that happened, the TRC never found the truth... The TRC did not help with justice. Because if the TRC was helping with justice, those that killed other people's relatives, they would punish them ...I was angry when I heard the stories, I get vexed more...Everybody not reconciled. Everything is not alright in Liberia. People are still divided.

This may be contrasted with a small businesswoman who, while she had heard of the TRC, did not monitor the hearings or recommendations:

Some people who did bad things during the war, they explained it. They brought confession. Now they fix it, everything is fine now...Yes, the TRC found out the truth everywhere. Found out the truth. (You think the TRC did justice for the Liberian people?) Of course. (Are you willing to forgive?) I am willing, I already forgive. (Do you think Liberia is reconciled from the war?) Yeah, let me say so. We forget about everything. We're moving freely now. I know we have forgotten.

The fact that she did not follow the Commission helped her to view Liberia as a reconciled nation, affecting her personal opinions accordingly. This somewhat ironic conclusion - that the body aiming to promote reconciliation in Liberia actually ended up 


\section{Peace and Conflict Studies}

further dividing those who followed it - echoes and elaborates on previous research (e.g., (Cruz Gitau, 2008; Harris \& Lapin, 2010; Steinberg, 2009).

\section{Discussion}

Most participants in this research felt that the TRC did not discover the full truth of the civil war's abuses. But more importantly, the truth that was discovered was not publicized in the right way. Warlords expressed little or no remorse, grandstanding and boasting about their actions. Accordingly, people who were exposed to their testimony, either through attending Commission hearings or through media coverage, generally perceived less reconciliation than those who were not exposed. In cases like these, "social forgetting” (Shaw, 2005) may be the more effective strategy. Alternatively, even if truth-seeking is pursued, truth-telling may be minimized. It is difficult to predict the tenor of testimony, but if future Commissioners were able to do so, it may be more effective in some cases to hold closed-door hearings for perpetrators, emphasizing the potential benefits of truth-seeking while minimizing the harms of divisive truth-telling.

As with the failure to uncover the right kind of truth, the TRC was often criticized as promoting the wrong kind of justice. Most participants who were knowledgeable about the TRC felt that it delivered either too much or too little justice. Commissioners attempted to chart a middle ground between restorative and retributive justice, recommending amnesties for lesser perpetrators and punishment for the more serious abusers, especially those who they felt did not express sufficient remorse for their actions (although this punishment has never been implemented). However, they failed to persuade Liberians of the wisdom of this middle path, resulting in dismay from all sides. Half of those interviewed for this study desired immediate retributive justice for wartime abusers, while the other half championed amnesty and forgetting. Hence, one group of Liberians was angered by what they perceived as divisive recommendations of prosecutions; the other was angered by what they perceived as too little action, enabling perpetrators to go free. In failing to draw significant public support for their actions, the truth commission alienated large segments of society, stranding itself in the center.

Future truth commission should issue a stronger more targeted message from day one, attempting to ensure public buy-in to their reconciliatory strategy. 


\section{Peace and Conflict Studies}

Reconciliation did appear to be linked to perceptions of the Commission's successes, hence, the data may be plausibly interpreted as supporting Minow’s (1998) stress on the importance of truth and justice. The more participants followed the Truth and Reconciliation Commission, the more they became aware of its failure to deliver truth or justice, and the less reconciled they became. Participants believed that national reconciliation would have been aided by (1) learning the full truth about violations, particularly if remorse was displayed, and (2) either by enforcing retributive justice or forgetting the past and moving on (neither of which approaches were successfully pursued). The perceived absence of these components, particularly given that hopes had been raised by the creation of the TRC, seems to have led to dismay and anger by those who followed the activities of the Commission, and subsequent decreased levels of reconciliation.

Of course, reconciliation does not happen overnight, even in the case that one learns the truth about abuses and receives an apology. Reconciliation, like forgiveness (Strelan \& Covic, 2006), likely requires a steady and concerted effort, as a society balances memory with progress. Thus, despite widespread dissatisfaction, it is important to consider the current findings as one time stamp in a much longer process. So too it may be helpful to conceive of the Commission as a longer-term endeavor, which does not finish with the tabling of a final report. It remains possible that the TRC may have longer-term effects yet to be seen. Although the hearings and the final report were problematic, the Commission made many potentially valuable recommendations: for example, \$500 million in victim reparations, as well as the creation of a National Palava Hut forum, a traditional conflict resolution mechanism (Truth and Reconciliation Commission of Liberia, 2009).

Additionally, the most successful transitions to new democracies appear to be characterized by initial amnesties and delayed prosecutions; truth commissions may act in concert with these mechanisms, emphasizing the stability of amnesties and the accountability of prosecutions (Olsen, Payne, \& Reiter, 2010, p. 1005). Although trials may be impossible in present-day Liberia due to the fragility of the peace process and the lack of a capable judiciary, they will not always be impossible. The evidence gained by the Liberian TRC has at the very least restarted a national debate (Weah, 2011). Its truth- 


\section{Peace and Conflict Studies}

seeking could prove useful in laying the groundwork for future prosecutions if Liberia one day decides that retributive justice is a desirable and feasible path.

\section{Limitations}

This study has several limitations. Above all, the present analysis is exploratory, and limited in depth by the necessary brevity and the scale of study undertaken. Thus, any findings should be interpreted as suggestive rather than definitive, and generalizations should be accepted with caution. A total of 45 people were interviewed for this study, all in relatively urban locations. Results may not generalize outside of the sample, particularly in more rural areas. Further, it is possible that there were preexisting differences between research sites attributable to factors other than the TRC, such as communal experiences in the war, demographic make-up, or local leaders (Sleh, Toe, \& Weah, 2008).

Finally, experience of violence is likely an influential variable in people’s perceptions of reconciliation. This topic was broached, but several participants chose not to answer, and among those that did, ordering results in terms of magnitude of suffering was deemed an impossible task. For example, did someone whose house was burned down suffer more or less than someone who lived in a refugee camp? Did someone whose husband was killed suffer more or less than someone whose child was raped? The few participants who had not suffered due to the war did appear to be more reconciled, which fits with existing literature on the impacts of victimization. Populations who have endured systematic human rights violations are less tolerant toward rights abuses and more supportive of prosecutions (Elcheroth \& Spini, 2009). Investigating the effects of experiences of violence on reconciliation in Liberia remains a task to be broached by future researchers.

With these limitations in mind we believe that the findings presented hold value. We believe that our categories are valid in as much as they are an accurate rendering of what our participants shared within the social context at hand. We have argued that the success of truth and justice as mechanisms for reconciliation depend in large part on how these concepts are understood and implemented locally. So too, external attempts to impose particular meanings may provoke reactance. Whether or not emergent themes generalize to Liberians as a whole does not detract from the findings of this investigation. 
Likely, value exists in uncovering some avenues for hope and others that may serve as barriers for reconciliation.

\section{Conclusion}

This paper highlights the importance of garnering individual reactions to societal transitions, a key component in the promising model suggested by Leidner and Li (2015) to investigate post-conflict justice mechanisms. Studies of bodies such as truth commissions are remiss if they ignore the ways in which real people receive these bodies. The way in which audiences make sense of, while accepting or rejecting, transitional efforts has a significant impact on their success. The TRC retains a positive symbolic impact, with most Liberians in favor of the Commission in principle. However, it appears to have alienated the majority of its audience, either through too much or too little justice, as well as insufficient or inappropriately revealed truth. Reconciliation is a long-term project, and the lasting effects of the Liberian TRC remain to be seen. However, in the short-term, this study indicates that the Commission failed to significantly advance reconciliation in Liberia, and in fact, may have harmed the nation's attempts to heal its wounds.

\section{References}

Bar-Siman-Tov, Y. (2004). Why Reconciliation? In Y. Bar-Siman-Tov (Ed.), From conflict resolution to reconciliation (11-38). New York, NY: Oxford University Press.

Bar-Tal, D. (2009). Reconciliation as a foundation of a culture of peace. In J. de Rivera (Ed.), Handbook on building cultures of peace (363-378). New York, NY: Springer.

Bell, C. (2009). Transitional justice, interdisciplinarity, and the state of the 'field' or 'non-field.' The International Journal of Transitional Justice, 3, 5-27.

Bloomfield, D., Barnes, T., \& Huyse, L. (Eds.) (2003). Reconciliation after violent conflict: A handbook. Stockholm, Sweden: International Institute for Democracy and Electoral Assistance.

Borneman, J. (2002). Reconciliation after ethnic cleansing: Listening, retribution, affiliation. Public Culture, 14, 281-304.

Collier, P., Hoeffler, A., Soderbom, M. (2006). Post-Conflict Risks. Centre for the Study of African Economics: Department of Economics, University of Oxford.

Charmaz, K. (2006). Constructing grounded theory: A practical guide through 
qualitative analysis. London: Sage.

Cruz Gitau, R. (2008). 'God willing, I will be back': Gauging the Truth and

Reconciliation Commission’s capacity to deter economic crimes in Liberia.

African Security Review, 17(4) 64-77.

Elcheroth, G., \& Spini, D. (2009). Public support for the prosecution of human rights violations in the former Yugoslavia. Peace and Conflict, Journal of Peace Psychology, 15, 189-214.

Ellis, S. (1999). The mask of anarchy: The destruction of Liberia and the religious dimension of an African civil war. New York, NY: New York University Press.

Freeman, M. (2006). Truth commissions and procedural fairness (1st ed.). New York: Cambridge University Press.

Gardner Feldman, L. (1999). The principle and practice of 'reconciliation' in German foreign policy: Relations with France, Israel, Poland and the Czech Republic. International Affairs, 75, 333-356.

Gberie, L. (2008). Truth and justice on trial in Liberia. African Affairs, 107(428), 455-465.

Gibson, J. L. (2004). Overcoming apartheid: Can truth reconcile a divided nation? New York, NY: Russell Sage Foundation.

Gilgun, J. F. (2005). Qualitative research and family psychology. Journal of Family Psychology. 19(1), 40-50.

Goldstone, R. J. (1996). Justice as a tool for peacemaking: Truth commissions and international criminal tribunals. New York University Journal of International Law and Politics, 28, 485-503.

Hamber, B. (1998). 'The burdens of truth: An evaluation of the psychological support services and initiatives undertaken by the South African Truth and Reconciliation Commission. American Imago, 55(1), 9-28.

Harris, D, \& Lapin, R. (2010). The Liberian Truth and Reconciliation Commission: Reconciling or re-dividing Liberia? Alternatives: Turkish Journal of International Relations, 9(1), 181-191.

Hayes, G. (1998). We suffer our memories: Thinking about the past, healing, and reconciliation. American Imago, 55, 29-50.

Hayner, P. (2007). Negotiating peace in Liberia: Preserving the possibility of Justice. Geneva: Center for Humanitarian Dialogue.

Hayner, P. (2011).Unspeakable truths: Transitional justice and the challenge of truth commissions. New York, NY: Routledge.

James-Allen, P., Weah, A., \& Goodfriend, L. (2010). Beyond the Truth and

Reconciliation Commission: Transitional Justice Options in Liberia. Monrovia, Liberia: International Center for Transitional Justice.

Kelman, H. C. (1999). Transforming the relationship between former enemies: A socialpsychological analysis. In R.L. Rothstein (Ed.), After the peace: Resistance and reconciliation (pp. 193-205). Boulder: Lynne Rienner Publishers.

Kriesberg, L. (2004). Comparing reconciliation actions within and between countries. In Bar-Siman-Tov, Y. (Ed). From conflict resolution to reconciliation (pp. 81-110). Oxford: Oxford University PressLambourne, 2009.

Kim, H, \& Sikkink, K. (2010). Explaining the deterrence effect of human rights 
prosecutions for transitional countries. International Studies Quarterly, 54(4), 939-963.

Lambourne, W. (2009). Transitional justice and peacebuilding after mass violence. The International Journal of Transitional Justice, 3, 28-48.

Landsman, S. (1996). Alternative responses to serious human rights abuses: Of prosecution and truth commissions. Law and Contemporary Problems, 59(4), 8192.

Lederach, J. P. (1997). Building peace: Sustainable reconciliation in divided societies. Washington, DC: United States Institute of Peace Press.

Leebaw, B. A. (2003). Legitimation or judgment? South Africa's restorative approach to transitional justice. Polity 36(1). 23-51.

Leidner, B. \& Li, M. (2015). How to (Re-)Build Human Rights Consciousness and Behavior in Post-Conflict Societies: An Integrative Literature Review and Framework for Past and Future Research. Peace and Conflict: Journal of Peace Psychology. In press.

Levitt, J. (2005). The evolution of deadly conflict in Liberia.Durham, NC: Carolina Academic Press.

Liberia National Housing and Population Census. (2008). Retrieved from http://www.emansion.gov.lr/doc/census_2008provisionalresults.pdf

Mendeloff, D. (2009). Trauma and vengeance: Assessing the psychological and emotional effects of post-conflict justice. Human Rights Quarterly, 31(3), 592623.

Millar, G. (2010). Assessing Local Experiences of Truth-Telling in Sierra Leone: Getting to 'Why' through a Qualitative Case Study Analysis. International Journal of Transitional Justice, 4(3), 477-496.

Millar, G. (2011). Local Evaluations of Justice through Truth Telling in Sierra Leone. Human Rights Review, 12(4), 515-535.

Miller, J., \& Glassner, B. (2004). The “inside” and the “outside”: Finding realities in interviews. In D. Silverman (Ed.), Qualitative research: Theory, method and practice (pp. 99-112). London, UK: Sage Publications.

Minow, M. (1998). Between vengeance and forgiveness: Facing history after genocide and mass violence. Boston, MA: Beacon Press Books.

Molenaar, A. (2005). Gacaca, grassroots justice after genocide: The key to reconciliation in Rwanda? Leiden: African Studies Centre.

Moran, M. (2006). Liberia: The violence of democracy. Philadelphia, PA: University of Pennsylvania Press.

Moosa, S. (2000). Truth and reconciliation as performance: Spectres of Eucaristic Redemption. In C. Villa-Vicencio \& W. Verwoerd (Eds.), Looking back, reaching forward: Reflections on the Truth and Reconciliation Commission of South Africa (pp. 113-122). Cape Town, South Africa: University of Cape Town Press.

Mullet, E., Neto, F., \& Pinto, M. (2008). What can reasonably be expected from a truth commission: A preliminary examination of East Timorese views. Peace and Conflict:Journal of Peace Psychology, 14, 369-393.

National Transitional Legislative Assembly. (2005). An act to create the Truth and 
Reconciliation Commission (TRC) of Liberia. Retrieved from http://www.ictj.org/static/Africa/Liberia/liberiatrcact.eng.pdf

Olsen, T., Payne, L., \& Reiter, A. (2010). The justice balance: When transitional justice improves human rights and democracy. Human Rights Quarterly, 32(4), 9801007.

Pupavac, V. (2004). International Therapeutic Peace and Justice in Bosnia. Social \& Legal Studies, 13(3), 377-401.

Quinn, J. (2005). The role of informal mechanisms in transitional justice. Paper presented on the panel, 'Transitional Justice: Local and International Dimensions,' at the Canadian Political Science Association Annual Meeting, London, Canada.

Randall, L \& Pulano, C. (2008). A review of media coverage of the truth and reconciliation process in Liberia. Monrovia, Liberia: Liberia Media Center.

Santayana, G. (1905). The Life of Reason, Volume 1. Retrieved October 2 2009, from http://www.gutenberg.org/etext/15000

Shaw, R. (2005). Rethinking Truth and Reconciliation Commissions: Lessons from Sierra Leone. Washington DC: United States Institute of Peace.

Sleh, A. C., Toe, G. T., \& Weah, A. B. (2008). Impunity under attack: The evolution and imperatives of the Liberian truth commission. Silver Spring, MD: Image Group Press.

Steinberg, J. (2009). Liberia’s experiment with transitional justice. African Affairs, 109/434, 135-144.

Strelan, P., \& Covic, T. (2006). A review of forgiveness process models and coping framework to guide future research. Journal of Social \& Clinical Psychology, 25(10), 1059-1085.

Supreme Court of Liberia. (2011). Petition granted in favor of Archie Williams.

Teitel, R. (2003). Transitional justice genealogy. Harvard Human Rights Journal, 16, 69-94.

Truth and Reconciliation Commission of Liberia. (2009). Final Report. Monrovia, Liberia: Author.

Twose, G. (2010). Going beyond truth in reconciliation. Review of International Affairs, LXI (2), 41-70.

Verdier, J. J. (2008). Statement by Cllr. Jerome J. Verdier, Sr., Chairman of the TRC, on the start of the public hearings. Retrieved from http://www.trcofliberia.org/hearings

Villa-Vicencio, C. (2004). Restorative justice. In C. Villa-Vicencio \& E. Doxtader (Eds.), Pieces of the puzzle: Keywords on reconciliation and transitional justice (pp. 33-38). Cape Town South Africa: Institute for Justice and Reconciliation.

Vinck, P., Pham, P., \& Kreutzer T. (2011). Talking peace: A population-based survey on attitudes about security, dispute resolution and post-conflict reconstruction in Liberia. Human Rights Center, University of California, Berkley - School of Law.

Weah, A. (2012). Hopes and Uncertainties: Liberia's Journey to End Impunity. International Journal of Transitional Justice, 6, 331-343.

Wiebelhaus-Brahm, E. (2010). Truth commissions and transitional societies: The impact on human rights and democracy. Abingdon, UK: Routledge, 2010. 
Williams, G. I. H. (2002). Liberia: The heart of darkness. Accounts of Liberia's civil war and its destabilizing effects in West Africa. Victoria, B.C., Canada: Trafford Publishing.

World Bank Group. (2011). World development report. Washington D.C.: Author.

Zhang, Y., Risen, J. L., \& Hosey, C. (2014). Reversing one’s fortune by pushing away bad luck. Journal Of Experimental Psychology: General, 143(3), 1171-1184. 